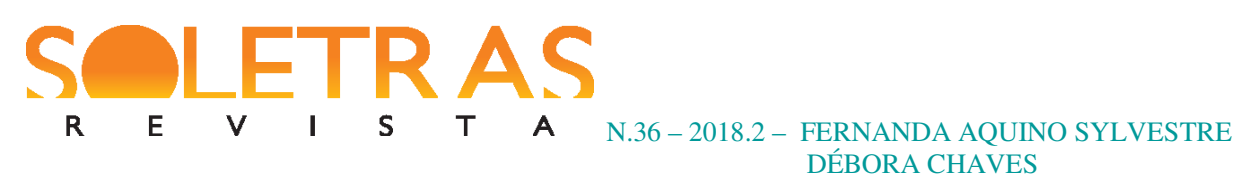

\title{
A gente se acostuma a tudo: os limites da ficção contemporânea
}

\author{
Débora Chaves ${ }^{1}$ \\ Fernanda Aquino Sylvestre ${ }^{2}$
}

Resumo: São muitas as abordagens direcionadas à compreensão do contemporâneo; a própria ficção contemporânea tem sido cada vez mais pesquisada e analisada no campo da literatura e por isso, tem ganhado novas formas e perspectivas dentro do universo investigativo. Através de lugares, experiências, memórias e narrativas, essa ficção vem aumentando seu leque de opção de leitura e de análise, construindo possibilidades bastante significativas, sobretudo no que diz respeito à literatura e ao jogo representacional que a envolve. Nos últimos anos têm surgido textos e produções literárias que questionam, denunciam, reconhecem ou simplesmente, analisam o lugar dessa ficção na contemporaneidade. A partir de três crônicas publicadas no livro A gente se acostuma a tudo, de João Ubaldo Ribeiro, esse artigo propõe um passeio pela narrativa ficcional, a partir de elementos que são reconhecidos em experiências cotidianas que formulam uma troca entre o autor, o narrador e o leitor. Com isso, o objetivo deste artigo é analisar o papel dessa ficção inserida na contemporaneidade, ressaltando traços que se materializam na memória, na representação e nas identidades, usando como base teórica autores como Agamben (2009), Benjamin (1994) e Ricouer (2007). Palavras-chave: Ficção contemporânea. Memória. Representação.

Na obra $O$ que é o contemporâneo? e outros ensaios (2009), Giorgio Agamben discute, desde a terminologia do contemporâneo até sua apropriação no entendimento da leitura de um texto ou de um documento do passado. Segundo ele, para entendermos o contemporâneo é necessário compreendermos "do que somos contemporâneos" ou mesmo o significado de ser contemporâneo, além de saber reconhecer a nossa contemporaneidade diante de textos e autores nos quais nos debruçamos para examinar.

A contemporaneidade exige de nós uma atualização, uma atualidade; há constante necessidade de revisitarmos o passado, a fim de atualizá-lo em relação ao presente e, consequentemente, desconectá-lo do seu tempo aparente para em seguida oferecê-lo a nossa necessidade de contextualização. Ser contemporâneo, então, poderia ser "aquele que não coincide perfeitamente com este, nem está adequado às suas pretensões e é, portanto, nesse sentido, inatual" (AGAMBEN, 2009, p. 58).

\footnotetext{
${ }^{1}$ Doutoranda em Estudos Literários pela Universidade Federal de Uberlândia (UFU), Uberlândia, MG, Brasil. Email:dekachaves@ig.com.br.

${ }^{2}$ Doutorado em Estudos Literários pela Faculdade de Ciências e Letras da UNESP de Araraquara. Professora Adjunta da Universidade Federal de Uberlândia. Professora permanente do Programa de Pós-Graduação em Letras da Universidade Federal de Uberlândia (UFU), Uberlândia, MG, Brasil. E-mail: fernandasyl@uol.com.br
} 
Com isso, observamos que o contemporâneo parte da singularidade de uma conexão com o tempo e essa conexão surge a partir do afastamento e do distanciamento que é construído a partir dele, pois é nesse afastamento que se torna possível olhar para o tempo sem estar carregado de seus aspectos mais influenciadores; do contrário, a percepção e olhar apurado sobre esse tempo estaria comprometido por uma aderência e por uma sedução que envolve, sorrateiramente, aquele que se compatibiliza plenamente com a época.

Mas há ainda outro tipo de contemporâneo, que, de acordo com Agamben (2009, p. 62), procura "manter fixo o olhar no seu tempo", agora, com o objetivo de identificar o contrário daquilo que se vê, ou seja, encontrar um sim diante do não, ou mesmo, enxergar o ficar, ao invés do partir; identificar aquilo que ninguém percebe pelo fato de o foco estar em outro holofote. Registra o autor:

Mas o que vê quem vê o seu tempo, o sorriso demente do seu século? Neste ponto gostaria de lhes propor uma segunda definição da contemporaneidade: contemporâneo é aquele que mantém fixo o olhar no seu tempo, para nele perceber não as luzes, mas o escuro. Todos os tempos são, para quem deles experimenta contemporaneidade, obscuros (AGAMBEN, 2009, p. 62).

Em resumo, todos os tempos são obscuros, escondem algo a nossos olhos. Para sermos capazes de decifrá-los, precisamos enxergar o invisível ou, simplesmente, enxergarmos aquilo que não se pode ser visto, a "não-visão". Essa ausência da visão ou "escuro da contemporaneidade" aponta para uma capacidade peculiar de decifrar o que está sendo apresentado para além da luz diante dos olhos.

Há fortes indícios de que a contemporaneidade está inscrita no presente, em aspectos que são constantemente revisitados e atualizados; mas há também uma percepção em relação ao passado que o aproxima da necessidade de subscrever o tempo, isto é, o contemporâneo deseja registrar aquilo que só pode ser observado a partir de um olhar diferenciado ou mesmo singularizado, a respeito daquilo que se quer examinar. Para isso é necessário, ainda, visitar as origens, a fonte, os segredos do tempo a que estão inseridos os objetos de análise e discussão. Por esse motivo, é tão forte a ação das conexões entre os tempos, pois nela está contida tanto a captação do instante, quanto a contextualização do seu desenvolvimento a partir desse instante.

Por essa razão, a escolha da análise das crônicas de João Ubaldo Ribeiro se tornou tão pertinente a esse estudo, uma vez que, além de sua capacidade de captar o tempo, a crônica 
também traz, desde seu registro, a necessidade de um olhar atento e singular, com o propósito de perceber nela tanto sua contextualização, quando a origem de sua construção enquanto texto literário. Mas antes de analisá-las, devemos pensar ainda em outro aspecto: em que ponto a memória e o contemporâneo se fundem?

\section{A memória e suas contribuições para o contemporâneo}

Ao situarmos o contemporâneo, notamos uma correspondência entre encontrar o escuro em meio à luz, na questão do tempo, uma vez que a escuridão se encontra no vazio das luzes (AGAMBEN, 2009). A memória e o esquecimento, discutido por Ricouer (2010), sugere que o esquecimento se dá na própria memória: no momento em que há esquecimento, no lugar onde anteriormente havia marcas. De acordo com Ricouer, o desejo de reconhecimento de uma determinada coisa ausente pode significar uma nova definição do presente; no caso do texto, trata-se de uma forma elementar de se compreender o seu andamento. Neste caso, Ricouer usa a afirmação de Aristóteles de que "a memória é do passado" para justificar um enfrentamento da correlação entre memória e imagem, vinculando a memória à temporalidade da condição humana.

Esse emblema da memória, intitulada por Ricouer como "aporia”, se desdobra, ainda, dentro da história, justamente pela condição subposta em que se encontra a narrativa histórica e a ficção literária. Com isso, a memória, que constantemente é exercida pelos sujeitos do discurso (e do poder), se posta como uma fonte enriquecedora de conhecimento, tornando-se, assim, elemento de utilização frequente nos estudos (desde os mais simples até os mais complexos) de representação da literatura. Em seu exercício constante, a memória é manipulada e adulterada, em função da manutenção de uma identidade individual ou coletiva. Essa memória coletiva, por exemplo, agrega e constrói identidades de grupos a partir de registros memorialísticos e históricos/sociais. Todavia, uma memória pode se tornar uma obrigação, especialmente pelo fato de estar condenada a um recordar, por estar associada ao não-esquecimento.

Ricouer (2010) ainda nos fala de um "dever de memória”, que traduz possíveis obrigações conferidas à memória no momento em que ela avança, no tempo como no espaço. Esse "dever de memória" se manifesta ainda no contexto de sua utilização, pois mesmo o 
autor contestando essas obrigações/deveres, não há como descartarmos a possibilidade de uma consonância entre passado e presente por meio da revisitação e/ou evocação da memória.

Sobre esse aspecto, podemos também ressaltar a observação de Samoyault (2008, p. 26), quando registra que:

Desde a origem, a literatura está duplamente ligada à memória. Oral, ela é recitada, seus ritmos e suas sonoridades são organizados de maneira que se inscrevam por muito tempo na memória. Seus próprios conteúdos procedem de uma obrigação de memória: coletivamente, é preciso recolher a gesta fundadora, coletar e registrar os altos feitos, as ações resplandecentes, uma estória constitutiva e constituinte. A origem está lá, na necessidade absoluta de precisar uma origem.

Ora, a crônica enquanto texto literário está completamente inserida nessa observação de Samoyault, especialmente por demonstrar os efeitos produzidos através de seu registro e conteúdo. A crônica recolhe diversas memórias e as transforma em narrativa, oferecendo ao leitor a comprovação e a confirmação de suas experiências em fatos do cotidiano, em personagens que são representados na sociedade e nos lugares que recebem o mesmo nome dos lugares familiares ao leitor.

Na primeira crônica selecionada para compor este artigo, observamos algumas dessas questões aqui trazidas. Na crônica intitulada "De volta à Real", de João Ubaldo Ribeiro, o cronista faz questão de registrar sua passagem pela, então, Ilha de Itaparica, sua terra natal, se esforçando para deixar a cidade, após um período de férias, conforme podemos conferir no trecho que segue:

Relutantemente, lembro que está na hora de deixar Itaparica. Neste domingo, já deverei encontrar-me de volta ao batente de sempre. Há uma melancolia irônica nisso, porque o paraíso terrestre só se alcança por tempo limitado. Como o casamento, de que já se disse ser igual a uma gaiola: o passarinho que está fora quer entrar, o que está dentro quer sair. É verdade e suponho que tem mesmo a ver com a natureza humana. Meu truque, em relação à ilha, é demorar o bastante para, ao deixá-la, ainda querer ficar. Assim preservo as saudades e o encanto do que revivi, nesses dias tão breves que acabo de passar. Não posso permanecer o resto da vida apenas assistindo às festas que, nesta época do ano, aqui parecem acontecer todos os dias, conversando e espiando os passarinhos, batendo papo com meus fantasmas e sendo docemente irresponsável, como se nada mais no mundo tivesse importância (RIBEIRO, 2006, p. 65-66). 
No trecho em destaque é possível notar certa necessidade, por parte do narrador, de buscar a figura da Ilha de Itaparica na memória de Ubaldo, a fim de transportá-la ou deslocála para o presente. Ao tecer suas experiências e narrar os dias em que estava desfrutando das férias em sua terra natal, esse narrador deixa transparecer um aspecto que envolve tanto a memória quanto o esquecimento. A memória, uma vez que revisita o passado com suas lembranças dos dias agradáveis e das festas que apreciou durante sua estadia; e o esquecimento, quando sugere que não quer pensar, lembrar ou se preocupar com as obrigações do cotidiano.

Interessante pensar que, ao inserir o termo "saudades", a voz do narrador adquire um tom melancólico, no entanto, não passa pelo sentimento de querer esquecer, e sim pela tentativa de captar aquele instante com o objetivo de fazê-lo durar um pouco mais do que o tempo cronológico é capaz de registrar. Nesse caso, a memória se constrói na ausência daquele ambiente de satisfação e de boas recordações que a personagem descreve com tanta intensidade e saudosismo.

Podemos ainda perceber que esse narrador também fala em "fantasmas", que ele chama de seus, demonstrando, assim, um sentimento de revisitação tanto de lugares, como de pessoas com as quais ele conviveu e convivia sempre que era possível. Em uma percepção espontânea, podemos dizer que esses fantasmas são representações de uma vida inteira construída e reconstruída na memória. Eles se configuram em lembranças e histórias que se confundem com a própria história do autor, em um discurso muito pessoal, por vezes íntimo, mas ao mesmo tempo interessado em convencer o leitor sobre sua relação com essa ilha.

\section{A crônica e a ficção contemporânea}

A crônica desempenha um papel significativo na contemporaneidade. Sua notoriedade, consistência e aceitação foram consolidando aos poucos, ao longo dos séculos, seu lugar na literatura, enfrentando o embate de ser ou não ser um texto literário. No entanto, ao ganhar espaço nesse terreno tão vasto que é a escrita, a crônica se tornou uma representante direta do armazenamento rápido da memória, por intermédio da captação e da intuição, transcrita por intermédio de signos curtos.

O espaço ficcional na crônica está inscrito por meio da distância dos critérios com que a verdade opera, distância esta que torna possível colocar essa verdade em perspectiva, 
indagando-a e pondo-a em evidência (LIMA, 1992, p. 54). O espaço ficcional na crônica também surge como uma instância crítica não interessada em propor outra verdade, ao contrário, ela torna a verdade questionável.

A matéria-prima da crônica é o cotidiano construído pelo cronista por meio de uma seleção que o leva a registrar aspectos mais relevantes e significativos de determinados eventos, e ainda, ao eleger uns, abandona outros, mostrando que, de fato, há uma seleção intuitiva ao escrever uma crônica. Podemos dizer com isso que a crônica é a narrativa do cotidiano que se alimenta da memória e da recordação para se firmar enquanto verdade, questionando todas as demais verdades que poderiam estar inseridas em si mesmas.

Há uma zona de convergência entre a ficção e a realidade que se firma na elaboração dos acordos simbólicos existentes entre essas verdades. Além do pacto ficcional entre leitor e autor, descrito por Philippe Lejeune e discutido por Noronha, em sua apresentação de $O$ pacto autobiográfico: de Rousseau à Internet (2008), como sendo um acordo que se estabelece entre leitor e texto, no sentido de não se questionar o estatuto fantasioso de uma obra, existe ainda um duelo implícito no ato da leitura, que o leitor deseja encontrar ao iniciá-la, bem como, ao escrever uma obra ficcional, o escritor acaba formulando que tipo de leitor deseja encontrar, embora ele não saiba exatamente o leitor que se dedicará a sua obra.

Para se ler uma obra de ficção, então, é preciso ter desprendimento, experiência e um campo apropriado para o desenvolvimento dessa ficção, principalmente por saber que a ficção trabalha com o mesmo processo de uma crença, de uma fé: depende muito (e quase totalmente) de quem a lê. Os modelos de realidade e da suposição acabam criando convenções que os tornam verdadeiros ou fictícios.

Há formas de pensamento teórico que nascem da ficcionalização. Poderíamos chegar ao entendimento de que, em sua forma escrita, a crônica está fundamentada na produção que se alimenta de um universo paralelo à realidade, universo esse que se desnuda, que se desconfigura no imaginário ou na produção de um imaginário que imita a realidade. Ou que, de fato, é outra realidade, como uma representação daquilo que se imagina ou se constrói na imaginação. É uma realidade que possibilita a concretização de tudo aquilo que a convencionalidade exclui ou critica, possibilitando toda e completamente a ficcionalização dos fatos dentro de sua narrativa.

Os modelos convencionais de "imitação" da realidade é que fazem dessa realidade uma ficção e a realidade se prende na ficção porque é essa ficção que a representa, que dita o 
que é ou não realidade, por meio da influência que se configura no âmbito da concretização ou da materialização desse imaginário; e o responsável direto por essa materialização é o leitor.

Sendo assim, para se ler ficção é preciso observar a contextualização do mundo e das leituras ao redor daquilo que se representa, em um mundo paralelo, construído na imaginação do escritor e concretizado por intermédio da aceitação desse leitor ao que está representando suas emoções, sensações e respostas para um mundo possível.

A ficção contemporânea apresenta diversas possibilidades de leitura, de interpretação e de reconstrução histórica. O fato é que cada obra de ficção traz em si uma representação daquilo que pode ser considerado real e, ao mesmo tempo, aquelas verdades que são constituídas dentro dos limites da ficção - no paralelo - outras verdades. De todo modo, a parte mais sensível para o entendimento (ou não) de uma obra de ficção está no leitor, que experimenta e vivencia a obra (no caso, a crônica), desde suas experiências de leitura até as que são consideradas experiências pessoais.

Vejamos mais um trecho da crônica de Ubaldo:

E o fato é que a Itaparica que lhes apresento não existe, não é possível que exista. Meus conterrâneos, apesar de talvez pitorescos para os olhos forasteiros, são gente como outra qualquer, com os defeitos e qualidades que se vêem em gente de qualquer parte. E, claro, não estão num mundo e num país à parte, têm problemas e angústias como todos os outros, embora amenizados por estes ares gentis, este sossego acolhedor, estas águas verdes e azuladas do mar da Bahia, estes bancos de areia sem fim, a Natureza despertando o poeta de meia-tigela que mora em tantos de nós. Para mim, em especial, ainda há umas sugestões fugidias da infância e da juventude cada vez mais remotas e mais romantizadas, uns cheiros, uns relances de paisagem, uns sentimentos que, de tão longínquos, já pareciam mortos [...] (RIBEIRO, 2000, p. 66).

Nesse trecho, o próprio narrador questiona a existência da Ilha de Itaparica apresentada aos seus leitores. Ou seja, embora haja uma ilha de Itaparica (geograficamente localizada no estado da Bahia), a ilha descrita na crônica é fruto da arte e engenhosidade daquele que pretende tecê-la apenas em sua construção ficcional. Há uma dosagem da realidade de uma ilha que faz com que a outra seja verossímil e existem personagens e descrições nessa outra que a torna ainda mais especial e significativa para aquele que a idealiza em sua memória. Durante todo o desenvolvimento da crônica, os acontecimentos se 
destacam em contradições e dúvidas, marcadas por essas personagens que integram o jogo da representação, da ficção e das identidades.

\section{Representação em destaque na literatura}

O problema da representação é de grande relevância para a ficção contemporânea. Ele se estabelece na condição de tornar real ou de tornar realidade algo que se constitui no ato da leitura e no seu desenvolvimento. Walter Benjamim (1994), em seu texto sobre a crise do romance, destacou que a construção de uma narrativa se dá pela necessidade da construção de um enredo para a humanidade, sendo assim, podemos parafraseá-lo, dizendo que, escrever uma crônica significa descrever a existência humana, levando do incomensurável ao paradoxal. Assim, a distância entre a representação e a história tem destaque na individualidade da escrita, ou mesmo, na ficcionalização da experiência. Com base nesta observação, destacamos, pelo menos, duas posições: a do indivíduo que escreve a ficção, construindo sua história com base no real da experiência; e daquele narrador que apresenta a narrativa aos leitores com sua voz convidativa e familiar, própria de um discurso contemporâneo. Esse narrador vai tecendo as ações, os fatos e as pequenas histórias registradas, possivelmente, com a intenção de envolver o leitor em uma teia ficcional, despretensiosa ou não, contudo, sua função parece atrair esse leitor para um comprometimento ficcional que vai além das linhas registradas, principalmente, ao inserir elementos que são facilmente reconhecidos por esse leitor.

Não se pode pensar que a representação é suficiente para sustentar sozinha esse comprometimento ficcional. Ao contrário, o que se nota é uma fragilidade em sua sustentação, marcada pela própria ausência de uma materialização dessa representação em si mesma, pois se trata de uma espécie de montagem, um apanhado de memória soltas que vão se juntando para formar uma história cronologicamente estruturada, ou apenas, temporalmente separada, mas coesa. É como se pequenas histórias fossem se juntando para produzir um sentido mais amplo dentro da crônica. E essas pequenas histórias só fazem sentido quando estão juntas.

A obra literária se alimenta dos restos daquilo que pode ser reformulado no dia seguinte ao que foi escrito e que, de acordo com o período e com a época em que está inserido, pode ser redirecionado a uma nova perspectiva (GARRAMUÑO, 2011). O mesmo 
acontece com a representação. Se em um determinado momento ela aparece para representar o que se insere em um contexto do real, logo em seguida ela será re-apresentada para cumprir um novo significado. Por essa razão, a leitura do texto ficcional se torna uma experiência tão particular para cada leitor/leitura, comprovando que a representação se configura na memória e por intermédio da memória.

A segunda crônica analisada nesse estudo é "Bom Domingo". Nela, João Ubaldo narra a experiência de um domingo de eleições para prefeitos e vereadores, no qual ele atualiza e contextualiza situações de diferentes épocas, a partir de um discurso aparentemente "nãoengajado" politicamente. O fato é que a voz do narrador ubaldiano é mais forte do que aquilo que o cronista procura assegurar em seu registro e, aos poucos, seu posicionamento e sua visão crítica vão surgindo na crônica, como podemos conferir:

\footnotetext{
É hoje. Não sei quanto a vocês, mas já cumpri o dever. Acordo cedo, sou ansioso e, possivelmente, terei aparecido e minha seção até antes dos mesários. E espero que ninguém esteja me lendo na fila, não só porque as filas hoje são raras e rápidas como porque ouvi falar que as autoridades estão muito rigorosas e qualquer observação que eu publique aqui poderá ser levada na conta da nefanda prática de boca-de-urna, que aliás, como vocês devem ter visto ou verão hoje, foi praticamente abolida. Não quero cometer nenhuma irregularidade eleitoral. Sei que isso não tem importância e que basta pedir desculpas depois, mas assim mesmo é mais seguro não facilitar (RIBEIRO, 2006, p. 127).
}

Interessante notar a atemporalidade dessa crônica. Embora tenha sido escrita no ano de 2004 e publicada em 2006, à medida que vamos lendo, vamos também percebendo a familiaridade dos acontecimentos com o cotidiano. A crônica estabelece uma relação tão próxima desse cotidiano que faz com que nós, leitores, tenhamos a garantia de uma experiência conjunta, seguindo as pistas deixadas pelo seu autor e reconhecendo as convenções e costumes sociais com os quais vamos nos adaptando e nos acostumando repetidamente.

Novamente, a confirmação dessas relações, em outro trecho da crônica anteriormente mencionada, nos aproxima do real humano quando o narrador traz a memória do leitor, não apenas por meio dos lugares específicos que o fará se reconhecer no texto, como também pelas figuras reconhecidamente transitáveis no universo político de conhecimento público no Brasil. Nesse caso, as pistas vão se unindo à memória para comprometer o leitor, com 
garantias, mas sem que este perceba que está sendo visivelmente envolvido em uma narrativa ficcional, que no fundo, não tem nenhuma intenção de ser real. Ubaldo registra:

Em Salvador, onde já votei e onde, dizem as más línguas (esse povo é muito maledicente, só fica reparando essas besteiras), a contribuição do presidente para a campanha do candidato do PT, diferentemente da de São Paulo, foi convidar o Dr. Antônio Carlos para jantar, não sei se a disputa está pegando e se, no frigir do acarajé, não haverá surpresas (RIBEIRO, 2006, p. 130).

Flertar com a memória social e política é um mecanismo da ficção contemporânea. Ao descrever sua experiência daquele domingo eleitoral, o narrador age como se estivesse atraindo seu leitor (especialmente aquele que lia regularmente suas crônicas de domingo) para uma viagem ficcional que ultrapassa as linhas registradas no texto. Mais uma vez vemos a presença dessa representação, pois, afinal, que dia é hoje? Por que ao ler essa narrativa nos reportamos ao domingo de eleição, independente do dia da semana que estamos debruçados sobre o texto? Que experiência memorialística é essa que nos conduz ao centro da ficção?

Samoyault (2008, p. 47) assegura:

A literatura se escreve com a lembrança daquilo que é, daquilo que foi. Ela a exprime, movimentando sua memória e a escrevendo nos textos por meio de um certo número de procedimentos de retomada, de lembranças e de reescrituras, cujo trabalho faz aparecer o intertexto. Ela mostra assim sua capacidade de constituir em suma ou em biblioteca e de sugerir imaginário que ela própria tem de si. Fazendo da intertextualidade a memória da literatura, propõe-se uma poética inseparável de uma hermenêutica: trata-se de ver e de compreender o que ela procede, sem separar esse aspecto das modalidades concretas de sua inscrição.

Ou seja, esse é o papel dessa literatura inserida no universo contemporâneo. Sua representação está carregada de memória e essa memória também se traduz em representação, como em um jogo circular, sem fim, especialmente pelo fato de comprovar que as modalidades concretas não se separam e por demonstrar que a memória se codifica nas lembranças e no esquecimento, enquanto as representações buscam na memória a comprovação daquilo que desejam apresentar como realidade.

Vejamos um pouco mais da crônica:

A verdade é que estou arrependido de haver trocado meu domicílio eleitoral. Devia ter continuado a votar em Itaparica, pelo menos era uma desculpa para 
tirar uns dias de folga, consultando as bases antes de escolher um candidato. Mas troquei, agora dá muito trabalho fazer nova alteração. Não, fico votando aqui pelo Rio mesmo, partilhando da mesma animação dos que os meus atuais concidadãos cariocas. Animação, afinal justificável, não devemos ser céticos ou cínicos quanto às mudanças que trará a posse dos novos eleitos, quem quer que venham a ser eles ou elas. Amanhã, podem ter certeza, será outro dia. Ou seja, segunda-feira, claro - que foi que vocês pensaram? (RIBEIRO, 2006, p. 130).

O trecho acima nos mostra como Ubaldo traz a memória coletiva para evocar uma memória individual. Ao voltar à Itaparica ele resgata um pouco mais de tudo o que já havia declarado ao leitor na primeira crônica que vimos. Seu relato, apesar de se mostrar apenas como observador do cotidiano, apresenta uma ideia de frustração com relação a ausência do lugar deixado. A elaboração ficcional é a grande responsável por todo esse trajeto de representação, memórias e identidades que se entrelaçam no discurso do narrador. É possível que na ficção esteja contida a subscrição necessária para a compreensão das experiências humanas, registradas ou não, idealizadas ou não, materializadas ou não.

Podemos observar que no campo da crítica literária ainda ocorre um grande embate teórico herdado desde o Romantismo, especialmente pelo fato de que grande parte do século $\mathrm{XX}$ presenciou uma corrente que tratava a literatura como uma forma de se desculpar, de se esconder, principalmente por representar a sociedade de forma indireta ou até mesmo por negá-la dentro de um contexto social e histórico. Piglia (2006) afirmou que, de certa forma, existe uma expectativa na escrita e na leitura da ficção. É como se, de alguma maneira, essa expectativa fosse um elo entre aquele que escreve uma obra de ficção e aquele que a consome - o leitor.

Com isso, podemos notar que a necessidade de registro é o que dá veracidade a um conto literário. A narrativa deixa de ser uma história inventada para se tornar narrativa baseada em fatos da realidade ou de uma possível realidade. A ficção supre a realidade, pois é ela quem cria, por intermédio da palavra, uma imitação do real, que posteriormente se manifestará na identidade e se desdobrará em representações, através do reconhecimento e da experiência. Todas essas questões presentes na origem e no registro podem ser notadas a partir da intertextualidade e dos desdobramentos possíveis dentro dela. Partindo da intertextualidade, então, cabe ao leitor perceber e encontrar os paradoxos do texto, a fim de criar condições para diferenciar o que é imaginação e o que pode ser considerado real (SAMOYAULT, 2008). 


\section{A crônica de João Ubaldo Ribeiro e outras questões}

As três crônicas escolhidas para compor este artigo foram publicadas juntamente com outras 42, reunidas no livro que se intitula "A gente se acostuma a tudo" (2006), de João Ubaldo Ribeiro. Essas crônicas foram publicadas entre 1999 e 2006, no jornal $O$ Globo e no jornal $O$ Estado de São Paulo. É uma coleção que, quase em sua maioria, trata de questões políticas do nosso país e as injustiças sociais que as envolvem. Dessas 45 crônicas, 18 citam a Bahia ou a ilha de Itaparica.

No texto de apresentação desse livro de Ubaldo, assinado por Ferreira Gullar, o crítico (também poeta, ensaísta, cronista, etc.) rotula o autor como "educador malcriado", salientando sua postura sincera e debochada ao lidar com a intelectualidade diante da crítica política e social. Gullar apresenta um João Ubaldo que não se limita aos assuntos da conjuntura política, mas que critica a ineficiência dos serviços públicos, que critica o aumento dos impostos, que critica o abuso das autoridades e que, algumas vezes, é apenas um cidadão comum, que perde a esperança de um país melhor, uma vez que se acostuma a tudo o que lhe é imposto (GULLAR apud RIBEIRO, 2006, p. 9-10).

$\mathrm{Na}$ última crônica que iremos analisar, é possível observar esse posicionamento do "a gente se acostuma a tudo", quando notamos que a literatura, sobretudo a ficção contemporânea acaba nos empurrando para essa conscientização. Logo de início, a crônica vai se desenvolvendo pela descrição do cotidiano, como veremos a seguir:

Acordei com pendores filosófico-sociológicos, com perdão da má palavra. É uma bela e ensolarada manhã outonal, em que uma brisazinha fresca balança as folhas dos pinhões roxos que agora resolveram dominar aqui o terraço. Faz muito tempo, trouxe uma mudazinha da Bahia e a plantei aqui. O pinhão roxo, como se sabe, tem notáveis poderes contra olho-grande, pragas, invejas e outros malefícios, sendo mesmo indispensável para os mais prudentes. [...] A pimenteira, aliás, às vezes sucumbe ao olhão; daí a figura do "olho de seca-pimenteira", temidíssima em Itaparica e da qual até meu pai já foi vítima. [...]A mudinha custou a medrar, cheguei a pensar que ia morrer de banzo. Esgarçada e parca de folhas, parecia uma planta do deserto. Adubada, creio que teve uma indigestão e passou moribunda mais de um mês, desenganada mesmo. Aos poucos, voltaram a brotar suas folhinhas mirradas e seus galhinhos esquálidos e ninguém dava nada por ela (RIBEIRO, 2006, p. 11). 
A riqueza no detalhe da explanação sobre o pinhão roxo e mais uma vez a inserção da Bahia em sua crônica faz com que João Ubaldo Ribeiro, cada vez mais, reafirme sua identidade por intermédio da memória, notadamente ao ficcionalizar uma Bahia para além dos limites da baía de todos os santos e, ainda, como um lugar imaginado, alimentado por uma realidade que estabelece uma identificação e um sentimento de proximidade para com esse leitor da crônica.

Com Ubaldo, acontecem duas situações que exprimem uma construção identitária: uma calcada no espaço geográfico, mapeado entre o eixo Rio-São Paulo-Bahia, construindo uma identidade carregada dos traços e das experiências vividas nesses lugares; e outra que o cronista insere personagens/pessoas com as quais conviveu/convivia nesses lugares ano após ano, comprovando que, mesmo depois de tantos trânsitos, deslocamentos e registros, ainda sentia necessidade de citá-las, como se estivesse autenticando a verdade em sua escrita.

Outras questões, no caso do Ubaldo, são relevantes para se pensar na construção identitária. Vale salientar o deslocamento realizado pelo movimento de romper com o lugar deixado e, ainda, o movimento migratório, ao deixar o Nordeste em direção ao Sul, como uma maneira de buscar um lugar de reconhecimento que, apesar de todos os esforços por parte das outras regiões, só era conseguido por aqueles que estavam no chamado "centro" dos acontecimentos.

De fato, houve uma migração, uma dispersão e uma construção dos territórios imaginados a partir dos territórios reais. Foi necessária a saída de Ubaldo da ilha de Itaparica para que ele fosse capaz de olhar para ilha de fora; para que ele pudesse ver outra ilha e, assim, construir uma Bahia que está sendo representada em sua ilha ficcional. Há uma fronteira entre a realidade e a ficção; entre o território geográfico e o território abstrato que traz para vida (real) uma ilha que servirá de cenário e de representação para o território ficcional; que se apresenta no momento em que Ubaldo toma para si essa ilha real e a converte em uma ilha ficcional, a fim de não abandonar aquele que era o seu lugar, a sua Bahia representada na ilha de Itaparica.

João Ubaldo, assim como tantos outros expoentes da literatura, retomou um movimento que já estava inscrito lá atrás, perdurando até o século XIX, de se vivenciar a situação, não importando o como se vivenciá-la, mas a necessidade de se vivenciar, sentir, tocar, provar para ficcionalizar. A necessidade de experimentar para traduzir em forma de texto essa experiência da ficção e da representação. 
Hoje, temos uma literatura da experiência; uma literatura que desnuda o mundo chamado real e o transforma em uma ficção, em uma autoficção, em uma narrativa de si, em uma autobiografia, enfim; hoje temos uma literatura que comporta cada vez mais representações e cada vez mais definições e, embora assustados algumas vezes, enquanto leitores, nos adaptamos e nos acostumamos a essas apropriações e a essas nomenclaturas que vão surgindo dentro da velocidade contemporânea (SOUZA, 2004).

A crônica "A gente se acostuma a tudo", de Ubaldo, prova-nos que, mesmo demonstrando um estranhamento diante das muitas novidades que nos são impostas, com o passar do tempo, dos anos, meses, dias e até mesmo horas, vamo-nos acostumando. Mesmo porque não é fácil confrontar, pois o confronto exige esforço, desgaste, conhecimento e tempo. Cito Ribeiro, acerca do dito acima:

[...] A gente se acostuma a tudo, filosofo eu, depois de mais um passeio circunspecto de planta em planta. [...] Acostumamo-nos também a ser tungados com regularidade e sem reclamar, pois igualmente nos acostumamos a que reclamar não adianta e pode dar até cadeia. Acostumamo-nos e esquecemos, como esquecemos, por exemplo, os não sei quantos empréstimos compulsórios [...] Esquecemos até mesmo que armaram um esquema para vender a todo proprietário de carro o tal kit de primeiros socorros, a que ninguém mais dá importância, mas que deve ter dado um rico dinheirinho a seus fabricantes e vendedores. Mas que houve de errado nisso, apenas pouco mais de $\mathrm{R} \$ 10,00$ por cabeça, custa nada ajudar industriais e comerciantes necessitados? O dinheiro já está nas mãos deles, foi tudo brincadeirinha, coisas de nosso divertidíssimo Brasil mesmo. [...] Claro, poucos de nós reconhecem que temos alguma coisa a ver com o que ocorre, mas temos, pois, afinal, somos cidadãos e partes desse todo de que nos queixamos. Tenho certeza de que acharíamos formas de afirmar e exercer plenamente nossos direitos, se nos dispuséssemos a isso, mas o problema é que já nos acostumamos, a gente se acostuma a tudo (RIBEIRO, 2006, p. 12-14).

A crônica em destaque provoca a memória do leitor. O movimento do kit de primeiros socorros foi um fato marcante para os brasileiros e provocou protestos, reclamações, notícias em diversos meios de comunicação diferentes, mas passou e caiu no esquecimento. Nossa intenção aqui não é afirmar que João Ubaldo estivesse registrando sua crônica de maneira despretensiosa e inocente, muito menos que estivesse usando esse discurso apenas para "vender" o jornal; certamente havia uma intenção extremamente política (da qual não iremos nos ater nesse momento) e, sobretudo, um sentimento de "acerto de contas" entre a realidade e a ficção, pois seria muito mais difícil suspeitar de uma crítica, quando ela vinha subscrita 
numa crônica de domingo. No entanto, queremos questionar a forma como o autor se alimenta de informações concretas, de lugares reais, que autenticaram suas obras e o inseriram no rol dos cronistas mais bem-sucedidos dos últimos anos.

Essa evocação da memória recente e a apropriação da história na narrativa do cronista fazem com que tenhamos uma visão ampliada acerca do papel da ficção contemporânea dentro do universo formador de opiniões e escolhas. É exatamente nesse registro que podemos notar a mudança no que diz respeito a forma como o autor, o narrador e o leitor estão diretamente ligados por intermédio da memória e da representação. É nesse registro que a literatura realiza seu trânsito e seu deslocamento dentro dos diferentes mundos (sejam eles reais ou ficcionais) que compõem as novas narrativas.

Contudo, acreditamos que o narrador na crônica de Ubaldo estava certo. Enquanto apresentava suas rápidas experiências do cotidiano, mantinha a denúncia da culpa e do consentimento com que os brasileiros lidavam (e ainda lidam) com a corrupção, com as desigualdades sociais, com as regalias políticas e com as injustiças de diversos seguimentos. Talvez essa tenha sido a maneira encontrada pelo autor de representar em seu texto literário aquilo que estava armazenado apenas em sua memória individual e coletiva.

Representando a opinião do autor (que deixou claro o seu posicionamento em diversas entrevistas ao longo dos anos), a fala desse Ubaldo da crônica mantinha a afirmação de quea culpa é nossa, toda nossa. Culpa pela mudança (positiva ou negativa), culpa pela aceitação do novo (em detrimento do que se tinha anteriormente), culpa pelas novas formas de se inscrever a literatura (e, consequentemente, registrá-la) e culpa pela aglomeração de teorias que vão se acumulando (e se atropelando) dentro da contemporaneidade.

Se fosse nos dias de hoje e João Ubaldo Ribeiro ainda estivesse entre nós (faleceu em 2014), escrevendo suas crônicas, provavelmente teria muito o que registrar. Com certeza faria alguma crônica debochada e articulada para criticar os "novos tempos", os "novos livros", as "novas literaturas"; talvez até mostrasse sua opinião a respeito de um ou outro recémocupante de uma das cadeiras na Academia Brasileira de Letras. Não saberemos. Com o tempo, talvez a gente se acostume com as novidades que ainda surgirão nessa ficção contemporânea e nessa literatura que parece acolher a tudo. Talvez a gente se acostume com nomenclaturas que ainda não foram descobertas ou mesmo não foram inventadas. Mas, certamente, saberemos lidar com essas novidades, ainda que com dificuldades; afinal de contas, "a gente se acostuma a tudo". 


\title{
Referências
}

AGAMBEN, Giorgio. A comunidade que vem. Belo Horizonte: Autêntica, 2013.

BENJAMIN, Walter. A crise do romance. In: . Magia e técnica, arte e política: ensaios sobre literatura e história da cultura. São Paulo: Brasiliense, 1994.

CANDIDO, Antônio. A crônica: o gênero, sua fixação e suas transformações no Brasil. Campinas, SP: Editora da UNICAMP; Rio de Janeiro: Fundação Casa de Rui Barbosa, 1992.

COELHO, Eduardo Prado. Os universos da crítica. Paradigmas nos estudos literários. Lisboa: Edições 70. 1978, p. 71- 99.

GARRAMUÑO. Florencia. Uma pedra no meio do caminho do real. In: OLINTO, Heidrun Krieger; SCHOLLHAMMER, Karl E. Literatura e realidade(s). Rio de Janeiro: 7Letras, 2011.

LEJEUNE, Philippe. O pacto autobiográfico: de Rousseau à internet. Belo Horizonte: Editora da UFMG, 2008.

NORONHA, Jovita Maria Gernheim. Apresentação. In: LEJEUNE, Philippe. O pacto autobiográfico: de Rousseau à internet. Belo Horizonte: Editora da UFMG, 2008, p. 7-10.

PIGLIA, Ricardo. Memoria y tradición. Anais do II Congresso ABRALIC. Belo Horizonte: UFMG, 1991, v. 1, p. 60-66.

RIBEIRO, João Ubaldo. A gente se acostuma a tudo. Rio de Janeiro: Nova Fronteira, 2006.

SAMOYAULT, Tiphaine. A intertextualidade. São Paulo: Aderaldo \& Rotschild. 2008.

SOUZA, Eneida Maria de. Nas margens, a metrópole. In: SANTOS, Paulo Sergio Nolasco (Org.) Divergências e convergências em Literatura Comparada. Campo Grande: Editora da UFMS, 2004, p. 15-26.

\section{We get used to everything: the limits of contemporary fiction}

\begin{abstract}
There are many approaches that help us to understand the contemporary. The contemporary fiction itself has been increasingly researched and analyzed in the field of literature and therefore it has gained new forms and new perspectives within the research universe. Places, experiences, memories and narratives have increased the ways of reading and analyze this kind of fiction, building quite significant possibilities, especially with regard to literature and the representational game that involves it. In the last years, many texts and literary productions appeared with the aim of questioning, denouncing, recognizing or simply, analyzing the place of this kind of fiction in the contemporary time. This article proposes a


ride through the fictional narrative by reading three chronicles published in the book A gente se acostuma a tudo, by João Ubaldo Ribeiro, from elements that are recognized in everyday experiences and that allow a change among the author, the narrator and the reader. The purpose of this article is to analyze the role of this fiction inserted in contemporaneity, highlighting traces that materialize in memory, representation and identities, using as theoretical basis authors such as Agamben (2009), Benjamin (1994), Ricouer (2007).

Keywords: Contemporary fiction. Memory. Representation.

Recebido em: 02 de maio de 2018.

Aceito em: 23 de junho de 2018. 